\title{
Sprawozdanie
}

\section{Ogólnopolska konferencja naukowa Stan nadzwyczajny jako zagadnienie polityczno-prawne, Zielona Góra, 16-17 października 2014 r.}

W dniach 16-17 października 2014 r. w Zielonej Górze odbyła się ogólnopolska konferencja naukowa nt. „Stan nadzwyczajny jako zagadnienie polityczno-prawne". Przedsięwzięcie było współorganizowane przez Instytut Politologii UZ oraz Wydział Prawa i Administracji UZ. Obrady odbywały się w Rektoracie Uniwersytetu Zielonogórskiego, gdzie w pięciu sesjach wystąpiło 23 referentów reprezentujących 11 ośrodków naukowych z całego kraju. Uroczyste otwarcie konferencji rozpoczęło się powitaniem gości i uczestników w imieniu Komitetu Organizacyjnego przez dr Joannę Markiewicz-Stanny z Katedry Teorii Prawa Wydziału Prawa i Administracji Uniwersytetu Zielonogórskiego. Następnie głos zabrali prorektor UZ prof. dr hab. Wojciech Strzyżewski i dziekan Wydziału Humanistycznego dr hab. Sławomir Kufel, prof. UZ. W zastępstwie nieobecnego dziekana Wydziału Prawa i Administracji prof. dr hab. Bogusława Banaszaka krótkie przemówienie wygłosił prodziekan dr Robert Wysocki.

Konferencja została pomyślana jako pole debaty między przedstawicielami nauk politycznych i prawnych, $w$ związku z czym zaprezentowane referaty tworzyły wieloaspektowe studium stanu nadzwyczajnego.

Sesja inaugurująca miała charakter ogólny i wprowadzający, a jako pierwsi wystąpili prof. Jerzy Menkes i dr Anna Kociołek-Pęksa (Szkoła Główna 
Służby Pożarniczej w Warszawie) z referatem pt. „Międzynarodowe i krajowe regulacje stanów nadzwyczajnych - analiza teoretyczno-prawna (systemowa)". Profesor Menkes postawił w nim między innymi pytanie o niezbędność przyjmowania określonych rozwiązań na poziomie konstytucyjnym, przy wskazaniu na różnorodną praktykę państw w tym zakresie. W tym kontekście prelegent podkreślił brak jednoznacznych i prostych zależności między podobieństwem doświadczeń historycznych poszczególnych państw a sposobem ukształtowania treści normatywnych regulujących stany nadzwyczajne.

Kontynuując referat, dr Anna Kociołek-Pęksa podniosła problem istotnych różnic $w$ metodologii badań politologicznych i prawniczych. Prelegentka postawiła wręcz tezę, iż z tego względu obrady konferencyjne mają charakter nie tyle interdyscyplinarny, co multidyscyplinarny. Dr Kociołek-Pęksa zauważyła, że w politologii wprowadzenie stanu nadzwyczajnego postrzega się i bada jako decyzję polityczną, która jest prawnie uwarunkowana, natomiast nauki prawne koncentrują się na prawnym charakterze tej decyzji i jej warstwie normatywnej, w niewielkim stopniu lub wcale nie odnosząc się do jej politycznego kontekstu. Wskazana odmienność podejścia obu nauk znalazła potwierdzenie w kolejnych dwóch referatach, poświęconych związkom między stanem nadzwyczajnym a zagrożeniem suwerenności państwa. Z jednej strony zostały ono przeanalizowane szczegółowo na gruncie polskiego prawa konstytucyjnego przez prof. Krzysztofa Eckhardta (Wyższa Szkoła Prawa i Administracji Rzeszów-Przemyśl) w referacie pt. „Stan nadzwyczajny jako środek ochrony wewnętrznej suwerenności państwa", a z drugiej strony pokazane w kontekście praktyki politycznej i doświadczeń państw w Europie Środkowej przez prof. Andrzeja Małkiewicza (Uniwersytet Zielonogórski).

W dyskusji kontynuowano rozważania nad modelami stanów nadzwyczajnych oraz celami, jakie mają one realizować. Mianowicie, czy tak jak to przedstawił profesor Menkes jest to instrument obrony przede wszystkim zagrożonego interesu obywateli, czy też jednak instytucja ta ex definitione koncentruje się na ochronie struktur państwowych i suwerenności wewnętrznej, o której mówił prof. K. Eckhardt. Wobec wygłoszonych przez dr Annę Kociołek-Pęksa zastrzeżeń, że w piśmie przewodnim konferencji postawiono problemy rozwiązane już w prawie polskim, autorka niniejszego sprawozdania wykazała, że konferencja z założenia nie dotyczy tylko 
polskiego porządku prawnego. W związku z tym w zaproszeniu konferencyjnym odniesiono się choćby do toczonych na gruncie innych systemów normatywnych sporów o granice kompetencji władzy sądowniczej w zakresie oceny decyzji i środków podjętych przez władzę wykonawczą w stanie nadzwyczajnym. Bezpośrednią egzemplifikacją może być prawodawstwo i praktyka brytyjska w sprawie A and others v. The United Kingdom, rozstrzyganej przez Europejski Trybunał Praw Człowieka ${ }^{1}$.

W następnej sesji, której przewodniczył prof. Andrzej Bisztyga (Uniwersytet Zielonogórski), dominowała problematyka międzynarodowa. Jako pierwszy wystąpił dr Wojciech Burek (Uniwersytet Jagielloński), wygłaszając referat pt. „Prawa niederogowalne a zagadnienie hierarchii praw człowieka”. Tytułowy problem został poddany analizie z perspektywy międzynarodowego prawa praw człowieka, ze szczególnym wskazaniem na brak jednolitego katalogu praw niederogowalnych, a także na stosunkowo nieliczną grupę traktatów zawierających klauzule derogacyjne.

Dr Marta Szuniewicz (Akademia Marynarki Wojennej) w referacie „Międzynarodowe prawo humanitarne w kontekście niederogowanej substancji praw człowieka" przedstawiła syntetyczne ujęcie relacji między zakresem przedmiotowym ochrony obu tych gałęzi prawa w sytuacji stanu nadzwyczajnego. Prelegentka zwróciła uwagę, że cały szereg praw niederogowalnych jest chronionych również w prawie konfliktów zbrojnych, czyniąc jednak zastrzeżenie, że dotyczy to konfliktów międzynarodowych; natomiast stosunkowo wąski jest katalog praw jednostki przewidzianych w przypadku wewnętrznych konfliktów zbrojnych, gdzie ma zastosowanie II Protokół Dodatkowy do konwencji genewskich.

Kolejny referat wygłosiła dr Joanna Osiejewicz (Uniwersytet Zielonogórski), koncentrując uwagę słuchaczy na stanie nadzwyczajnym w sytuacji zagrożenia bezpieczeństwa dostaw gazu ziemnego w UE. Szczegółowej analizie zostały poddane regulacje prawa europejskiego, a także ich implementacja w prawie polskim.

Jako ostatnia zabrała głos dr Agnieszka Wedeł-Domaradzka (Uniwersytet Kazimierza Wielkiego), wygłaszając referat „Dziecko w stanie nadzwyczaj-

$A$ and others $v$. The United Kingdom, skarga nr 3455/05, wyrok ETPC z dnia 19 lutego $2009 \mathrm{r}$. 
nym - uwagi na tle prawa międzynarodowego". Było to precyzyjne studium obowiązujących norm prawa międzynarodowego, które zostało opatrzone komentarzem dotyczącym najpoważniejszych naruszeń praw dziecka w trakcie stanów nadzwyczajnych, takich jak przymusowy pobór do armii, eksploatacja seksualna, nielegalne adopcje czy handel dziećmi. W trakcie dyskusji, w której uczestniczyli prof. Andrzej Bisztyga, prof. Krzysztof Eckhardt, a także dr Wojciech Burek, nastąpiła ożywiona wymiana zdań na temat celowości tworzenia hierarchii praw człowieka. Ostatecznie dyskutanci doszli do wniosku, że aczkolwiek sama konstrukcja praw niederogowalnych prowokuje do takich poszukiwań, to jednak jest to zabieg sztuczny, zwłaszcza że, jak zauważył dr W. Burek, o niederogowalności danego prawa niekoniecznie przesądza jego „ranga”.

$\mathrm{Z}$ kolei w nawiązaniu do referatu dr M. Szuniewicz prof. J. Menkes wygłosił pogląd, że problemem prawa humanitarnego w kontekście wewnętrznych konfliktów zbrojnych jest nie tyle uboga warstwa normatywna, co brak jej znajomości i związania nią podmiotów niepaństwowych, biorących udział w konflikcie. Dr Karol Dobrzeniecki (Uniwersytet Mikołaja Kopernika) również w odniesieniu do tego referatu postawił pytania o to, co referentka rozumie pod pojęciem obniżenia poziomu ochrony praw jednostki, a także o dopuszczalności stosowania w stanie nadzwyczajnym środków ograniczających prawa i wolności całych grup społecznych, etnicznych bądź też religijnych, tak jak miało to miejsce w USA podczas II wojny światowej. W tym miejscu do dyskusji włączyła się także autorka tego sprawozdania, wskazując, że współcześnie jedynym kryterium zastosowania internowania zgodnie z międzynarodowym prawem humanitarnym nie może być przynależność do określonej grupy i musi przebiegać w oparciu o zindywidualizowaną ocenę, czy dana jednostka zagraża bezpieczeństwu państwa, co znajduje potwierdzenie w orzecznictwie Międzynarodowego Trybunału do spraw Zbrodni w byłej Jugosławii.

Ogólne rozważania nad problemem stanu nadzwyczajnego prezentowane w sesji otwierającej znalazły swoją kontynuację w trzeciej części obrad, skoncentrowanej w obszarze myśli politycznej, filozofii i teorii prawa. Przewodnictwo objął prof. Andrzej Małkiewicz, który przekazał głos dr. Tomaszowi Banaszakowi (Uniwersytet Zielonogórski). Jego referat zatytułowany był „Wojna jako składowa pokoju w myśli klasycznego liberalizmu”. Dr T. Bana- 
szak postawił tezę, że wojna postrzegana przez liberałów jako źródło porządku prawnego sprzed umowy społecznej nie została przez tę umowę społeczną wyeliminowana całkowicie. Prelegent wskazywał, że w klasycznej myśli liberalnej silny był choćby wątek prawa społeczeństwa do samoobrony. Swoistą kontynuację tych rozważań stanowiło wystąpienie dr. Piotra Szymańca pt. „Adam Fergusson i rewolucja. Z rozważań nad posłuszeństwem obywatelskim i granicami obowiązywania porządku prawnego w myśli Zachodu”. Następny referat pt. „Stan nadzwyczajny z perspektywy filozofii prawa” wygłosił dr Karol Dobrzeniecki (Uniwersytet Mikołaja Kopernika). Szczególną zaletą tego wystąpienia była refleksja nad obserwowanym współcześnie zderzeniem treści obowiązujących norm prawnych z ewolucją zjawisk i zagrożeń, jakie łączą się ze stanem nadzwyczajnym. Przedostatni referent, dr Łukasz Jakubiak (Uniwersytet Jagielloński), przedstawił interesujące studium przypadku, jakim jest recepcja regulującego stany nadzwyczajne art. 16 Konstytucji V Republiki Francuskiej w państwach Afryki frankofońskiej. Sesję zamknęło wystąpienie dr Elżbiety Czerny-Drożdżejko zatytułowane „Ograniczenie wolności mediów w stanach nadzwyczajnych”. W referacie prelegentka akcentowała pewną nieadekwatność i brak aktualności polskiego prawodawstwa w przedmiotowym obszarze, a także wieloletni już brak przepisów wykonawczych.

W dyskusji doszło do polemiki między dr. T. Banaszakiem a dr. P. Szymańcem odnośnie do tego, czy umowa społeczna była koncepcją właściwą całej klasycznej myśl liberalnej. Głos zabrał również prof. Jacek Sobczak (Szkoła Wyższa Psychologii Społecznej), wypowiadając pogląd, że część niedostatków polskiego ustawodawstwa może być rekompensowana treścią art. 10 Europejskiej Konwencji o Ochronie Praw Człowieka i Podstawowych Wolności, a także bogatym orzecznictwem Europejskiego Trybunału Praw Człowieka w tym przedmiocie. Prelegentka przyznała rację profesorowi, ale podkreśliła, że starając się w sposób wyczerpujący omówić regulacje prawa krajowego, z uwagi na dyscyplinę czasową nie zdążyła przejść do międzynarodowych.

W drugim dniu obrad przewodnictwo pierwszej sesji objął prof. Jerzy Menkes, a inauguracyjne wystąpienie pt. „Stan nadzwyczajny w Republice Białorusi" należało do prof. Jacka Sobczaka. Było to obszerne studium, zawierające nie tylko rozważania poświęcone przepisom stricte regulującym 
stany nadzwyczajne, ale też ukazujące istotę systemu politycznego i prawnego tego państwa. Kolejne wystąpienia stanowiły już bezpośrednią i rozległą analizę prawa oraz praktyki polskiej. Mgr Łukasz Łukowski (Uniwersytet Łódzki) w referacie „Stan klęski żywiołowej a powódź z 2010 r. - czy normy ustanawiające stany nadzwyczajne służą obywatelom?" zwracał uwagę na polityczne uwarunkowania decyzji o wprowadzeniu stanu nadzwyczajnego. Jako przykład podał brak ogłoszenia stanu klęski żywiołowej pomimo niezwykle rozległego charakteru powodzi z 2010 r. ze względu na to, iż zgodnie z obowiązującymi przepisami musiałoby wtedy dojść do przełożenia wyborów prezydenckich. Następny referent, dr Michał Zieliński (Uniwersytet Zielonogórski), aczkolwiek zastrzegł, że zarówno na poziomie konstytucyjnym, jak i ustawowym polskie regulacje prawne zasługują na dobrą ocenę, to jednak wskazał na przynajmniej kilka niedostatków. Referent poruszył problem wątpliwości interpretacyjnych odnośnie rozumienia konstytucyjnego sformułowania „jeśli środki konstytucyjne są niewystarczające”; odniósł się także do braku normatywnych zabezpieczeń przed sztucznym przedłużaniem kadencji wybieralnych organów państwa w przypadku wprowadzenia stanu klęski żywiołowej. W wystąpieniu nie zabrakło wskazania braku aktualności art. 228 ust. 6 Konstytucji RP, który odwołuje się do uchylonych już przepisów ordynacji wyborczych. Szereg krytycznych refleksji wygłosił także dr Norbert Banaszak (Uniwersytet Zielonogórski) w referacie poświęconym administracyjnoprawnym konsekwencjom wprowadzenia stanów nadzwyczajnych. Dość naturalnym obszarem badań w przypadku stanu nadzwyczajnego jest prawo publiczne, zwłaszcza zaś konstytucyjne i administracyjne, ale pole do wypowiedzi znalazł także przedstawiciel doktryny prawa cywilnego w osobie mgr. Jakuba Głowacza (Uniwersytet Łódzki), który wygłosił referat na temat „Prywatnoprawna kwalifikacja stanów nadzwyczajnych i jej skutki”.

W dyskusji głos polemiczny zabrała dr Anna Kociołek-Pęksa, wskazując, że postulowane de lege ferenda przez mgr. Ł. Łukowskiego przekazanie kompetencji wojewody w stanach klęski żywiołowej samorządom wymagałoby przemodelowania całego systemu i mija się z celem, zważywszy na ścisłe podporządkowanie wojewodzie służb powołanych do zwalczania tego typu zagrożeń.

Na tym tle z praktycznego punktu widzenia cenny był komentarz Waldemara Kłaka, Dyrektora Wydziału Bezpieczeństwa i Zarządzania Kryzyso- 
wego Lubuskiego Urzędu Wojewódzkiego. Zwrócił on uwagę, że tak bardzo pożądane czy też postulowane przez gminy ogłoszenie stanu klęski żywiołowej na ich obszarze nie powoduje uruchomienia automatycznie żadnych dodatkowych środków finansowych z budżetu państwa, o które z reguły przecież chodzi. Natomiast odpowiednie środki budżetowe pozostają w dyspozycji wojewody na poziomie zarządzania kryzysowego.

Ostatnią część obrad prowadził prof. Ryszard Zaradny (Uniwersytet Zielonogórski); pierwszy referat dr Niny Leśniak (Uniwersytet Zielonogórski) stanowił kontynuację sesji pierwszej i był poświęcony zagadnieniu ochrony środowiska w stanach nadzwyczajnych na tle prawodawstwa polskiego. Jako druga wystąpiła dr Joanna Szymoniczek (Instytut Studiów Politycznych Polskiej Akademia Nauk), która skupiła się na rozstrzygnięciu kwestii, czy ogłoszenie stanu klęski żywiołowej jest warunkiem uzyskania pomocy humanitarnej. Rozważania prelegentki miały charakter szerszy i odnosiły się również do przypadków poważnych kryzysów humanitarnych o skali międzynarodowej. Ostatnim referentem konferencji był mgr Patryk Petrus (Uniwersytet Zielonogórski), którego referat był zatytułowany „Obrona konieczna: między instynktem a stanem nadzwyczajnym”. W dyskusji podniesiono uwagi krytyczne pod adresem tego ostatniego wystąpienia. Dr Elżbieta Czerny-Drożdżejko, a także dr Piotr Szymaniec dowodzili, że z punktu widzenia języka prawnego i prawniczego sposób, w jaki mgr P. Petrus zestawił ze sobą pojęcia obrony koniecznej i stanu nadzwyczajnego, jest trudny do zaakceptowania. Autorka tego sprawozdania zauważyła jednak, iż prelegent reprezentuje filozoficzny punkt widzenia, w związku z czym zarzuty te nie są w pełni adekwatne. Pomimo to uczestnicy obrad byli zgodni, że nawet biorąc pod uwagę, że mgr P. Petrus jest filozofem, powinien zaprezentować wystąpienie spójniejsze metodologicznie.

Konferencyjne obrady uroczyście zamknął Dyrektor Instytutu Politologii Uniwersytetu Zielonogórskiego prof. Ryszard Zaradny, zapraszając uczestników konferencji do opublikowania pisemnych wersji wystąpień w planowanej monografii.

Joanna Markiewicz-Stanny Uniwersytet Zielonogórski 